\title{
Cerodontha (Poemyza) unisetiorbita Zlobin, 1993 (Diptera: Agromyzidae), a leaf-miner on bamboo: first records from Central Europe
}

\author{
Miloš Černý \& Jindřich Roháček
}

Cerodontha (Poemyza) unisetiorbita Zlobin, 1993 (Diptera: Agromyzidae), a leaf-miner on bamboo: first records from Central Europe. - Acta Mus. Siles. Sci. Natur., 64: 91-96, 2015.

\begin{abstract}
Cerodontha (Poemyza) unisetiorbita Zlobin, 1993 (Diptera: Agromyzidae) is added to the fauna of the Czech Republic and Germany, based on rearing records from the Zoological garden Zlín-Lešná (Czech Republic) and from the Bamboo garden near Hannover (Germany). The distribution and biology of $C$. (P.) unisetiorbita are reviewed. The new records are given with illustrated habitat and host-plant data and photographs of living females, puparium and a hymenopterous parasitoid (Braconidae) reared from the puparium, and their significance is discussed.
\end{abstract}

Key words: Diptera, Agromyzidae, Cerodontha (Poemyza) unisetiorbita, new records, Czech Republic, Germany, distribution, biology

\section{Introduction}

The Agromyzidae, or "leaf miners“, is a family of Acalyptrate Diptera with 3,017 phytophagous species unequally distributed in 30 genera. The host-plants are currently known for only $42 \%$ of the agromyzid species which are distributed in 146 families and 899 genera of plants (Benavent-Corai et al. 2005). The genus Cerodontha Rondani, 1861, with seven subgenera (Butomomyza Nowakowski, 1967; Cerodontha Rondani, 1861; Dizygomyza Hendel, 1920; Icteromyza Hendel, 1931; Phytagromyza Hendel, 1920; Poemyza Hendel, 1931 and Xenophytomyza Frey, 1946) comprising altogether 291 species is the most diverse group of the the family Agromyzidae. The most species-rich subgenus Poemyza Hendel, 1931 includes 81 species distributed in all the biogeographical regions of the world. A total of 30 species belonging to Poemyza are currently known from Europe (Nowakowski 1973; Zlobin 1984, 1986, 1993). Species of Poemyza are miners of leaves of grasses (Poaceae) but the information about their biology has hitherto been available for only 29 species of the subgenus worldwide. Only 3 leaf miner species of the subgenus Poemyza are known to use bamboo species (subfamily Bambusoideae) as host-plants (Spencer 1990, Benavent-Corai et al. 2005) of which only Cerodontha (Poemyza) unisetiorbita Zlobin, 1993 is also known from Europe. This species was described from Japan (Zlobin 1993) and its occurrence was later also confirmed from Italy (Süss 2001). The new records from the Czech Republic, Germany (presented and discussed below) and Switzerland („Rai Hannover“ 2013) demonstrate that this species is spreading in Europe; the locality from Hannover (Germany) represents at the moment the northernmost limit to the occurrence of $C$. $(P$.) unisetiorbita in Europe. The high number of the mined leaves found on host-plants, as well as the number of reared specimens, indicate that the occurrence of the species is already firmly established in these localities (see below).

\section{Material and methods}

The majority of the material recorded below is deposited in the private collection of the senior author (M. Černý coll.); the rest is in the entomological collection of the Silesian Museum (SMOC). All specimens were reared from larvae and puparia found in mined bamboo leaves. Larvae were left in leaves placed in microtene bags up to the pupariation. For rearing adults the puparia were removed from mines and placed separately in small glass vials, corked by rolled blotting paper enabling air exchange and suitable humidity. Vials with puparia were put in a small plastic box with foam plastic which was regularly wetted by drops of water. The emerged adults were captured and kept separately but killed only after 24 hours when sufficiently hardened and no longer 
teneral; subsequently they were dry-mounted on triangular pinned cards together with associated (empty) puparia. The same method holds for the hymenopterous adults reared from the parasitised puparia.

A few living specimens were retained in plastic tubes to be photographed after their emergence in special glass boxes by means of a digital camera (Canon EOS 60D) with a macro lens (Canon MP-E 65 mm 1-5×) and ring macro flash (Canon MR-14EX). Dry-mounted specimens have been examined using two types of binocular stereoscopic microscopes (Reichert, Olympus). Host plants and their leaves with mines were photographed by a digital camera Panasonic Lumix DMC-FS7.

\title{
Results
}

\section{Cerodontha (Poemyza) unisetiorbita Zlobin, 1993}

\author{
(Figs 1-3, 5, 6)
}

Material examined: CZECH REPUBLIC: Moravia, Štípa near Zlín, ZOO Zlín - Lešná, 49¹6'24"N, 17²4'39"E, 265 m a.s.l., 11.viii.2014, on Phyllostachys nuda, ex. puparium in leaf mine, adults emerged 13.viii.2014, $1 \delta 3$ O , 14.viii.2014, $1 \hat{\jmath}$; the same locality 14.viii.2014, ex. puparium in leaf mine, adults emerged 15.viii.2014, $2 \hat{\jmath}$, 16.viii.2014, 2q, 20.viii.2014, 1ㅇ, 21.viii.2014, 1 + (the latter 2 q photographed), all M. Černý leg. and det. (coll. M. Černý; 2 i in SMOC). GERMANY: Northern Germany, Lower Saxony, Hannover, bamboo garden, 5.x.2014, on Phyllostachys atrovaginata, P. parvifolia and P. aureosulcata, ex. puparium in leaf

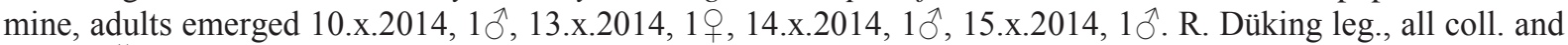
det. M. Černý.

Biology: In Europe C. (P.) unisetiorbita was reared from from mines on bamboo Phyllostachys mitis (Lour.) A. et C. Riv. in Italy (Süss 2001) and later (2013) the mines were recorded on Phyllostachys sp. a Fargesia sp. in Switzerland („Rai Hannover“ 2013). The host plant species confirmed by rearing from the Czech Republic is Phyllostachys nuda McClure while in Germany they are Phyllostachys atrovaginata C. S. Chao \& H. Y. Chou, P. parvifolia C. D. Chu et H. Y. Chou and P. aureosulcata McClure. There is no information about the host plant species in the type locality in Japan (Zlobin 1993); the first brief description and illustration of the mine was given by Süss (2001: Fig. 5). The larva forms a pale green, short and relatively broad linear mine (Figs 4, 7) on upper side of the leaf; the older mines are somewhat browned. In a larger leaf more larvae can mine together and their mines can sometimes be connected. The pupariation occurs in the leaf mine. Puparium (Figs 5,6 ) is reddish brown to brown, $1.65-1.85 \mathrm{~mm}$ long, somewhat dorsoventrally flattened; intersegmental grooves are slightly wrinkled and shallow; posterior spiracles long, each with 8-9 bulbs. Several puparia of $C$. (P.) unisetiorbita from $P$. nuda in ZOO Zlín - Lešná were parasitised by a braconid species (see Fig. 8). According to preliminary identification by J. Lukáš (Bratislava, Slovakia) it is probably a species of the tribe Opiini Blanchard, 1845 (Braconidae).

Distribution: Japan (Zlobin 1993), Italy (Süss 2001), Switzerland („Rai Hannover“ 2013), Czech Republic and Germany (first records).

\section{Discussion}

The leaf miner C. (P.) unisetiorbita was described by Zlobin (1993) from a series of specimens found in Japan (Kyushu Island: Kitakyushu). This species very closely resembles C. (P.) bisetiorbita Sasakawa, 1955 being known from Japan and Taiwan but is characterized in having orbital setulae in a single row, the ultimate section of vein $\mathrm{M}_{3+4}$ long, about 1.8 times as long as penultimate and legs entirely black. The specimens studied from C. Europe have legs lighter, with fore knees and tarsi pale brown. The structures of the male genitalia of these two species are distinctly different (cf. Sasakawa 1961: Fig. 49c, d, e, f and Zlobin 1993: Figs 77-81).

The occurrence of C. (P.) unisetiorbita in Evrope was first recorded in 2000 and 2001 from Italy (Süss 2001), where it was reared from mines on wild growth of bamboo Phyllosta- 


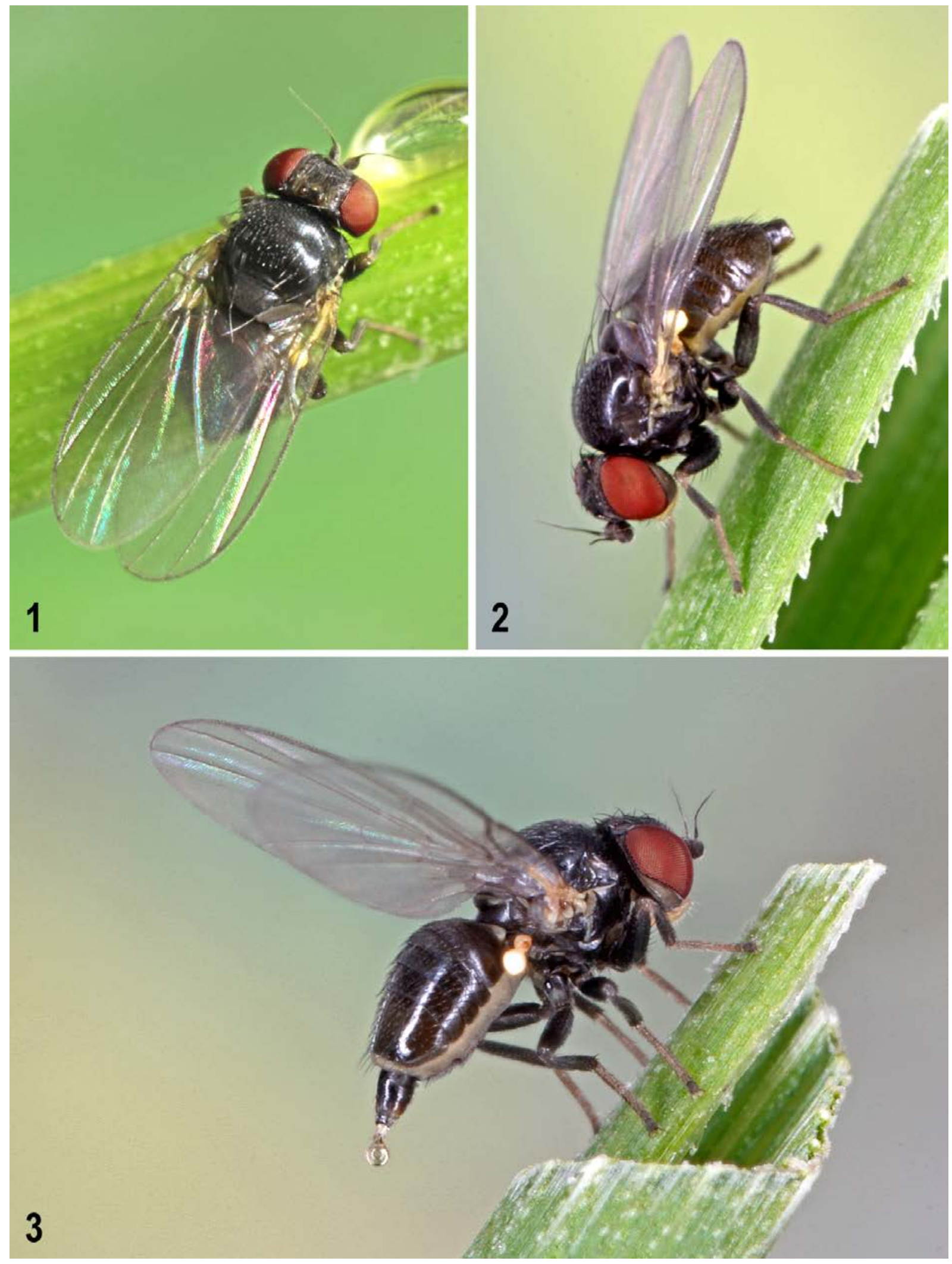

Figs 1-3: Adults of Cerodontha (Poemyza) unisetiorbita Zlobin from the Zoological garden Zlín-Lešná: 1 female, dorsally; $\mathbf{2}$ - same, laterally; 3 - another female specimen, laterally. Body length cca 2.0 mm. Photo by J. Roháček. 


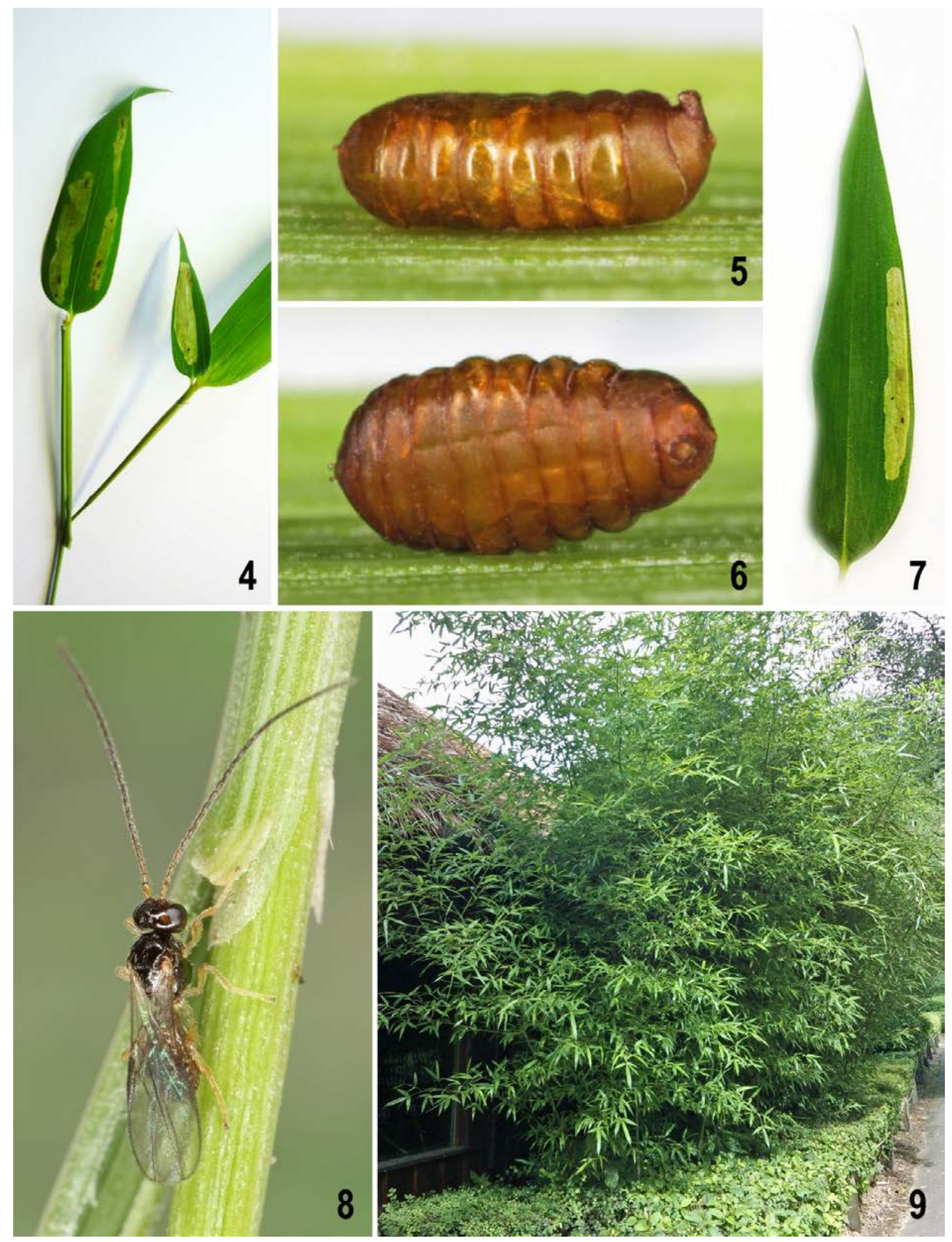

Figs 4-9: Mines, puparium, parasitoid and host plant of Cerodontha (Poemyza) unisetiorbita Zlobin: 4 a mined bamboo leaf of Phyllostachys nuda; $\mathbf{5}$ - puparium, laterally, length cca $1.8 \mathrm{~mm}$; $\mathbf{6}$ - same, ventrally; 7 detail of mine on bamboo leaf; 8 - Braconidae gen. sp. reared from puparium, dorsally, length cca 1.4 mm; 9 habitat with host plant $P$. nuda in the Zoological garden Zlín-Lešná. Photo by J. Roháček (Figs $5,6,8)$ and M. Černý (Figs 4, 7, 9). 
chys mitis on a site situated at $460 \mathrm{~m}$ a.s.l. near Arizzano in the vicinity of Lago Maggiore in the province Verbania and subsequently also in a private garden in Milano. In spring 2001 it was recorded from the same host plant in Liguria: Pozzuolo in the province La Spezia. Skuhravá et al. (2010) listed also its occurrence from Albania, referring to Süss (2001), but this information is incorrect because there is no such record in Süss (l. c.). In August 2013 mines of C. (P.) unisetiorbita have been found in growths of bamboo species Phyllostachys sp. and a Fargesia sp. in a bamboo garden near Zürich (Switzerland). On August 28th, 2013 the first photographs of mines and puparium and later (10.ix.2013) also first photograph of an emerged adult were published on Diptera.info („Rai Hannover“ 2013). Subsequently, in summer 2014 the mines of the same species have been found by the senior author on Phyllostachys nuda in ZOO Zlín - Lešná, in Štípa near Zlín (Czech Republic). The identical mines were also found on the species Phyllostachys atrovaginata, P. parvifolia and P. aureosulcata „spectabilis“ in a bamboo garden in Hannover (Germany). All adult flies reared from puparia from the latter two populations clearly belonged to $C$. (P.) unisetiorbita.

The bamboo growth in ZOO Zlín - Lešná was planted about 10 years ago; the seedlings of Phyllostachys nuda originated from China: Zhejiang, Fu Jian, Anhui. The bamboo species in the bamboo garden near Hannover also originate from China. Seedlings of Phyllostachys atrovaginata were from Jiangsu and Zhejiang, those of Phyllostachys parvifolia were imported in 1990 from Zheijang, near Hangzhou (region around Anji) and Phyllostachys aureosulcata „spectabilis“ was originally discovered in 1974 in the northern China and in 1987 imported to Hannover. Many Phyllostachys species from China have a long history of cultivation in Japan. Thus it is not always possible to reveal the origin of the bamboo species imported to Europe. Because the occurrence of leaf miners (Agromyzidae) in bamboo growths has hitherto not been specially investigated it can be expected that $C$. $(P$.) unisetiorbita will also plausibly be found in other countries of Europe and/or America where various bamboo species are planted from seedlings imported from China or Japan.

Note: While this paper was in print, a review of the occurrence of C. unisetiorbita in Europe, including records from Switzerland and Germany (Hannover), and with a note about it being found in the Czech Republic, also appeared on web, see http://forum.bambus-deutschland.de/kpp/index.php/ContentEntry/71-Die-Bambusminierfliege-Cerodontha-unisetiorbita/

Acknowledgements: We would like to thank the staff of the ZOO Zlín-Lešná (Czech Republic) for data about the origin of bamboo seedlings planted in this ZOO and to Mr. R. Düking (Hannover, Germany) for the material of mined bamboo leaves with larvae as well as for information about the origin of bamboo species growing in their bamboo garden. We are also grateful to Mr. P. Chandler (Melksham, England) for his comments and language corrections of the manuscript. The study of the junior author (J. Roháček) was financially supported by the Ministry of Culture of the Czech Republic by institutional financing of long-term conceptual development of the research institution (the Silesian Museum, MK000100595), internal grant of the Silesian Museum No. IGS201505/2015.

\section{References}

Benavent-Corai J., Martinez M. \& Jiménez Peydró R. (2005): Catalogue of the hosts-plants of the world Agromyzidae (Diptera): Part 1: List of Agromyzidae species and their hosts-plants. Part II: List of hosts-plants and Agromyzidae associated.- Boll. Zool. Agrar. Bachicoltura, Ser. II, 37(Suppl.): 1-97.

Nowakowski T. J. (1973): Monographie der europäischen Arten der Gattung Cerodontha Rond. -Annls Zool. 31(1): 1-327.

Sasakawa M. (1955): New Agromyzidae from Japan X. Species of the genus Phytobia. - Sci. Rep. Saikyo Univ. Agric. 7: 62-72.

- (1961): A study of the Japanese Agromyzidae (Diptera). Part 2. - Pac. Insects 3(2-3): 307-472.

Skuhravá M., Martinez M. \& Roques A. (2010): Diptera. Chapter 10. In: Roques A et al. (Eds) Alien terrestrial arthropods of Europe. - BioRisk 4(2): 553-602.

Spencer K. A. (1990): Host Specialization in the World Agromyzidae (Diptera). Series entomologica 45, Kluwer Academic Publishers, Dordrecht, xii + 444 pp. 
Süss L. (2001): Cerodontha (Poemyza) unisetiorbita Zlobin (Diptera Agromyzidae) nuova per l'Europa. Boll. Zool. Agrar. Bachicoltura, Ser. II, 33(1): 73-77.

Zlobin V. V. (1984): Mining flies of the genus Cerodontha Rondani (Diptera, Agromyzidae) from the USSR. II. Subgenus Poemyza, muscina-group. - Diptera (Insecta) of the fauna of the USSR and their significance in ecosystems, p. 45-54 (in Russian).

- (1986): Review of mining flies of the genus Cerodontha Rondani (Diptera: Agromyzidae) of the fauna of the USSR. III. Subgenus Poemyza atra-group. - Proc. Zool. Inst. Leningrad 140: 85-91 (in Russian).

- (1993): Review of mining flies of the genus Cerodontha. IV. Subgenus Poemyza (Diptera: Agromyzidae). Zoosyst. Rossica 1(1992): 117-141.

„Rai Hannover“ (2013): http://www.diptera.info/forum/viewthread.php?forum_id=4\&thread_id=56490. (actualized 28.8. 2013).

Cerodontha (Poemyza) unisetiorbita Zlobin, 1993 (Diptera: Agromyzidae), vrtalka minující na bambusu: první nálezy ve stř̌ední Evropě.

Vrtalka Cerodontha (Poemyza) unisetiorbita Zlobin, 1993 (Diptera: Agromyzidae), původně popsaná z Japonska, je novým druhem pro faunu střední Evropy, který byl nově zjištěn v České republice a v Německu. Druh byl vychován z larev a pupárí nalezených v minovaných bambusových listech v Zoologické zahradě ZlínLešná (Česká republika) a v bambusové zahradě u Hannoveru (Německo). Je podán přehled rozšíření a bionomie tohoto druhu doplněný o nové poznatky ze střední Evropy. Faunistické údaje jsou doplněny novými informacemi o biotopu a hostitelských rostlinách a fotografiemi živých samic, pupária, min na bambusových listech a parasita $\mathrm{z}$ čeledi Braconidae vypěstovaného z pupária, s diskusí významu těchto nových údajů o výskytu tohoto druhu v Evropě.

Authors’ addresses: Miloš Černý, CZ-763 63 Halenkovice 1, Czech Republic;

E-mail: cerny.milos@centrum.cz.

Jindřich Roháček, Slezské zemské muzeum, Nádražní okruh 31, CZ - 74601 Opava, Czech Republic; E-mail: rohacek@szm.cz. 